\title{
Piotr Rykała
}

University of Economis in Katowice

e-mail: piotr.rykala@ue.katowice.pl

ORCID: 0000-0003-2031-0383

\section{THE GROWTH OF THE GAMING INDUSTRY IN THE CONTEXT OF CREATIVE INDUSTRIES}

\section{ROZWÓJ SEKTORA GAMINGU W KONTEKŚCIE PRZEMYSEÓW KREATYWNYCH}

DOI: $10.15611 /$ br.2020.1.10

JEL Classifaction: L10, L19, O33, 044

\section{(C) 2020 Piotr Rykała}

This work is licensed under the Creative Commons Attribution-ShareAlike 4.0 International License. To view a copy of this license, visit http://creativecommons.org/licenses/by-sa/4.0/

Quote as: Rykała, P. (2020). The growth of the gaming industry in the context of creative industries. Biblioteka Regionalisty. Regional Journal, (20).

\begin{abstract}
This paper aims to provide an overview of the studies and literature regarding creative industries, with particular consideration of the video game industry, and define potential areas of further research, among others regarding e-sports. The author seeks to define creative industries, describe the Polish and global video game industries, point to their characteristics and present the development of the Polish and global video game markets providing the examples of the conducted research. The study involves a survey of literature sources, mainly covering the themes related to creative and video game industries, seeks to analyse the global and Polish video game markets based on the data from domestic and international reports.
\end{abstract}

Keywords: creative industries, innovation, computer games, computer games industry.

Streszczenie: Artykuł ma charakter teoretyczny, natomiast jego celem jest próba dokonania przeglądu badań oraz literatury w dziedzinie przemysłów kreatywnych z uwzględnieniem sektora gier komputerowych, a także zdefiniowanie potencjalnych badań, w tym uwzględniających e-sport. W tekście przedstawiono, czym są przemysły kreatywne, jak wygląda oraz czym charakteryzuje się branża gier komputerowych, ukazano, jak rozwija się rynek gier komputerowych na świecie i w Polsce, a także 
zaprezentowano przykładowe kierunki badań prowadzonych w ramach sektora gier. W ramach badań przeprowadzone zostały studia literaturowe w głównej mierze skupiające się na zagadnieniach z dziedziny gospodarki kreatywnej oraz sektora gier komputerowych. W tekście podjęto próbę analizy rynku gier komputerowych na świecie oraz w Polsce na podstawie danych pozyskanych z krajowych i międzynarodowych raportów.

Słowa kluczowe: przemysły kreatywne, innowacyjność, gry komputerowe, sektor gier komputerowych.

\section{Introduction}

Creative industries are among the most promising economic sectors in the world. They generate a significant value and provide a large number of jobs. The computer games market is one of the fastest-developing industries of this sector. With the development of personal computers and fast Internet, computer games have gained worldwide popularity and generate more than USD 150 billion of annual revenues (Newzoo, 2019). It is worth noting that this rise of computer games has become an attractive topic to investors and scientists, alike.

The paper consists of four sections and aims to provide an overview of studies and literature on creative industries, including the video game industry, and define potential further research, among others covering e-sports. This study seeks to define creative industries, demonstrate what the Polish and global video game industries are like, point to their characteristics and present the development of the Polish and global video game markets and the examples of research conducted in the field of the video game industry. The final section consists in the conclusions. The present paper includes a review of literary sources, mainly concerning the themes related to creative and video game industries to investigate global and Polish video game markets based on the data from available reports, and the presented research involved the use of the monographic method and document analysis.

\section{Creative industries}

Creativity is in today's world a crucial driving force behind economic growth. The evolving creative thoughts drive the emergence of new technologies, concepts and definitions as well as the development of literature and art, among others and contribute to the image of humanity which has a crucial impact on its surroundings.

The idea of creative industries first appeared in the United Kingdom in the late 20th century. In 1997, the Department of Culture, Media and Sport, or DCMS for short, was founded, comprising the interdisciplinary Creative Industries Task Force, the now Department of Culture, Olympics, Media and Sport (DOMCS). In 1998, DOMCS delivered a report entitled "Creative Industries Mapping Document", which sought to define creative industries (Pięta-Kanurska, 2013), which specified the 
industries in question as follows: "The industries responsible for these products are a varied bunch, yet they have certain things in common. Such industries make their profits from the creative skills of their workforce and the generation of intellectual property (IP), and collectively have come to be known as the creative industries" (DCMS, 1998). The report also defined thirteen sectors that make up the creative industry: Software and Computer Service, Design, Television and Radio, Interactive Leisure Software, Publishing, Music, Film and Video, Advertising, Art and Antiques Market, Architecture, Fashion Design, Performing Arts, and Crafts.

While seeking to define the whole creative industry and its sectors, one mainly relies on products created by that industry based on intellectual property, and so the definitions within this line of thought yield a catalogue of all human activities that drive creativity in a given place (Cellmer, 2012). It is argued that creative industries originate from the concept of cultural industries. They involve goods and services produced and distributed by enterprises and private individuals (Klasik, 2010). The operations conducted on macro and micro levels encompass products and services related to the broadly defined culture (Fesel and Sondermann, 2007).

The studies dedicated to creative industries are closely related to the idea of the creative class and the creative city, both dating back to the 1980s (Florida, 2002). At the time, the concept of creativity took on a special significance as it concerned all innovative actions, regardless of their affiliation with science, administration or business (Drobniak, 2012).

In Florida's view, traditional local communities are characterized by strong ties and create and distribute all benefits inwards. Now, the looser connections among inhabitants can accommodate newness, including new ideas, which leads to the creation of 'creative capital'. The paradigm of creative capital is that creative individuals are the driving force behind cities' and regions' social and economic development. What complements creativity-related notions is another term offered by Florida: 'the creative class', or a group of creative employees in the city's total workforce that is marked by $3 \mathrm{~T}$ : technology, talent and tolerance. Talent and tolerance apply only to the creative class (Florida, 2005).

It should be noted that, in addition to the 'first' classic approach, there are other definitions and models of the creative economy and the creative industries in economic practice. One such example is Trosby's model (Figure 1).

The core of the model consists of principal artistic products such as literature, music, performing arts and visual arts. The next level includes other industries involved in the creative process such as film, museums, galleries, libraries and photography. The third circle includes institutions and industries related to cultural heritage protection, publishing, radio and television, recording studios and computer games. The last and widest circle comprise cultural industries such as advertising, art and architecture. 


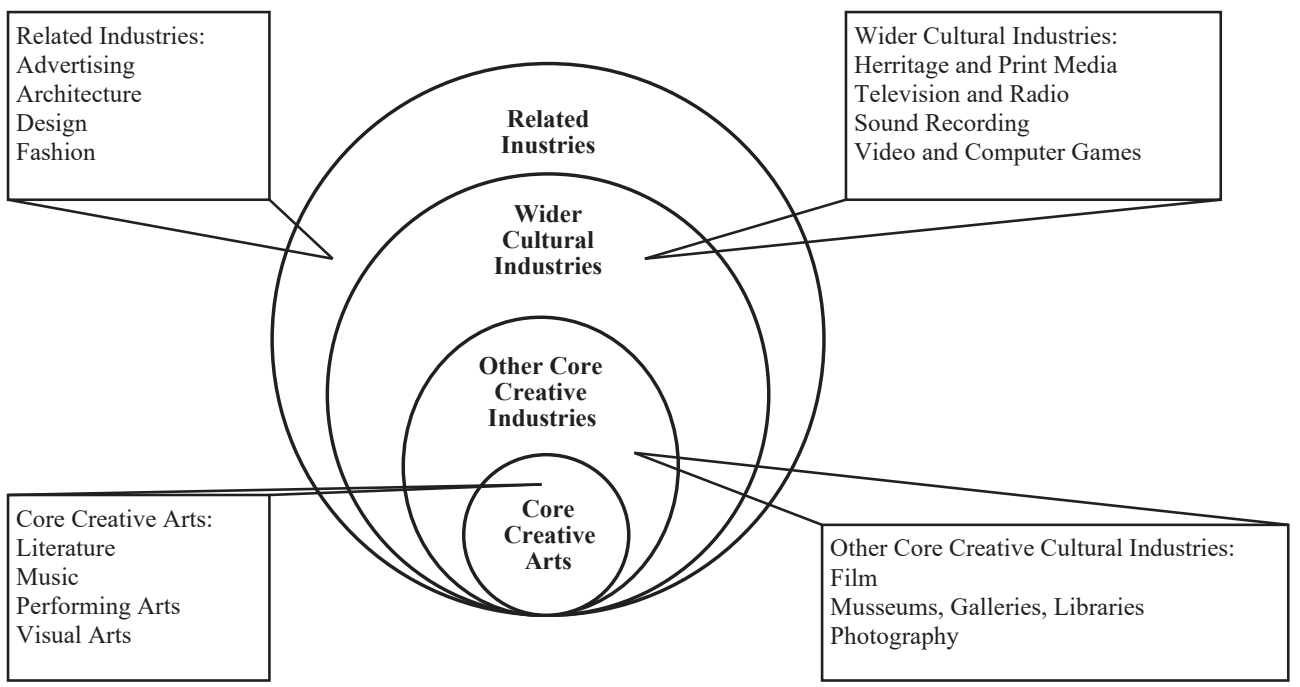

Fig. 1. The concentric circles model of the cultural industries

Source: (Throsby, 2008).

Klasik (2011) claims that creative industries can be defined on the basis of types and forms of intellectual property as they make up the foundation of modern economy, particularly in metropolitan and urban areas.

Table 1. Types of creativity and forms of intellectual property behind creative industries

\begin{tabular}{|c|c|c|c|c|}
\hline Type of activities $\begin{array}{r}\text { Type of intellectual } \\
\text { property }\end{array}$ & Copyrights & $\begin{array}{l}\text { Project and utility } \\
\text { models }\end{array}$ & Patents & Trademarks \\
\hline Artistic and cultural creativity & + & + & & + \\
\hline $\begin{array}{l}\text { Scientfic and technological } \\
\text { creativity }\end{array}$ & + & + & + & \\
\hline Business, public and civic creativity & + & + & & + \\
\hline
\end{tabular}

Source: (Klasik, 2011).

A closer look at creative industries from the perspective of how they impact on cities and regions allows us to specify four groups of creative industries (Potts and Cunningham, 2008, p. 2). The first group comprises those mainly aimed at shaping the quality of life. The second one is made up of creative industries that follow market and competition rules. The third group comprises the industries that generate jobs in related industries. The last group covers creative industries mainly aimed at driving innovative processes in a broad sense (Klasik, 2010). 


\section{Characteristics of the gaming industry}

Culture and cultural industries are some of the elements of the creative industry. One can distinguish between two main types of culture: high culture and pop culture. The gaming industry is considered to be part of pop culture and dates back to the early days of personal computers, mobile phones and the Internet (Drobniak, 2012).

Games and rivalry have always been an intrinsic part of human life, and after J. Huizinga published the famous study "Homo Ludens," in 1938, they became an attractive subject of scientific inquiry both from philosophical and sociological point of view. The author distinguished between three typical features of any game: participation in a game is voluntary and in-game action is isolated from real life; games impose their own rules applicable to all participants; each game creates a community that seeks to keep the relationships, even after the game ends (Huizinga, 1992). Finally, the rise of technology and fast Internet has brought new types of games and thus new industries, and computer games are increasingly replacing traditional games and contribute to the growth of the digital society.

What exactly is a computer game? According to Zackariasson and Wilson, a computer game is a special kind of digital entertainment in which the participant interacts with the digital interface and tackles various challenges, depending on the type of a game (2009). The authors distinguish three kinds of features which apply to all kinds of games:

1) settings - specific to a given genre, plot and interface;

2) sensory stimuli - experienced by players while playing;

3) rules - applicable in all games.

Juul offers a definition of a game with six main features: games have their own rules; games have variable results; different results are scored differently; the player has to make an effort to achieve a good score; the score affects the player emotionally; the game may or may not generate real consequences for the player. The development of the gaming industry brings more and more gaming genres, yet the author claims that these features are applicable to all types of games (Juul, 2005).

The literature shows that in the creative industry, which includes the computer gaming industry (Scholz, 2012), the development of products (e.g. computer games) relies on cooperation between different types of autonomous organizations and individuals (Balland, Boschma, and Franken, 2012). The particular significance of relationships between the actors within the gaming industry is due to the specific nature of the product itself.

The modern computer, console, mobile, web-browser and video games are very complex products. The process of developing a game requires an interdisciplinary approach, including from the artistic (graphic design, sound and literature) and business (marketing, strategies) perspectives. The complexity of any gaming product requires a mix of the creative and non-creative skills of employees within various 


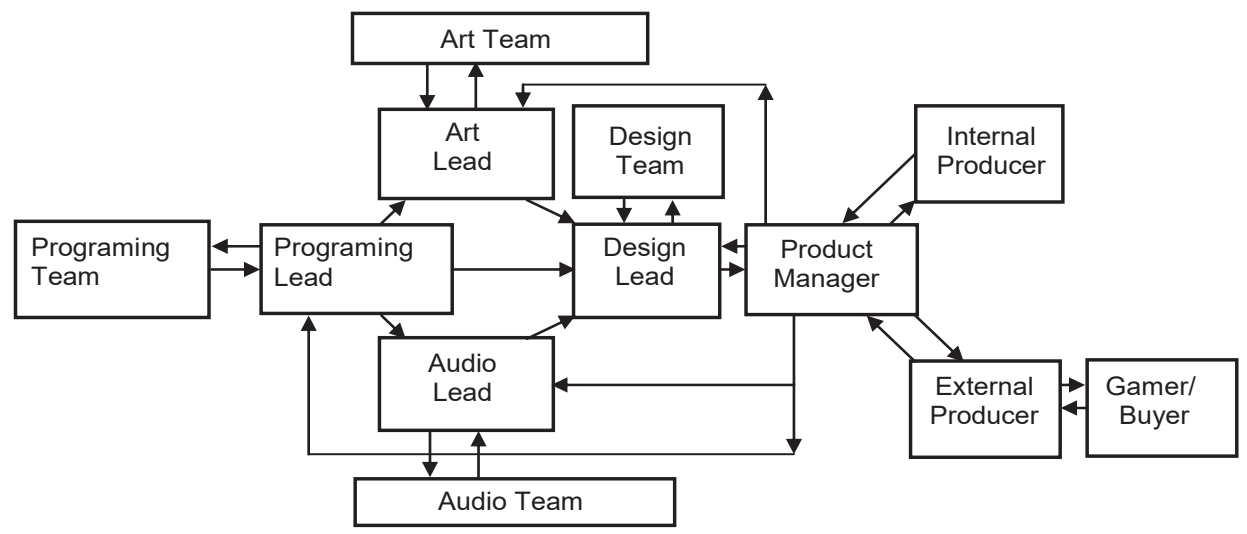

Fig. 2. Example of organization and workflow of a video game developer

Source: (Zackariasson and Wilson, 2009).

industries and organizations (Tschang, 2007) and thus many different individuals. One person or team is responsible for each aspect of a game and work together for the final product. Consequently, a game development process is not a linear undertaking that can be easily represented with a Gantt graph since it relies on cooperation between individual groups.

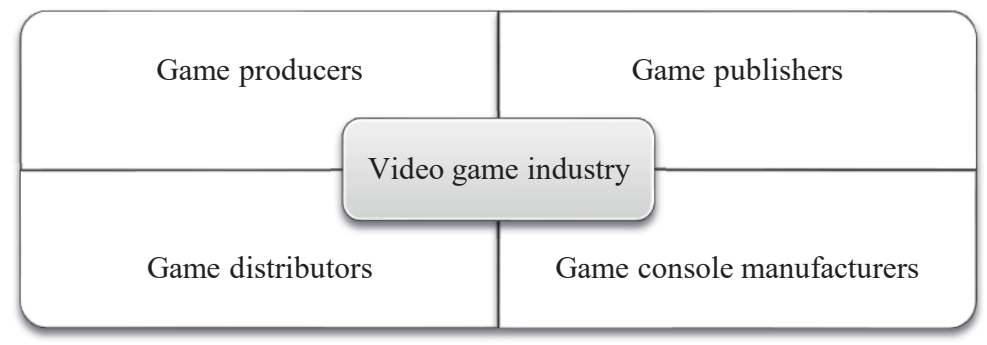

Fig. 3. Model of video game industry

Source: (Cadin and Guerin, 2006, pp. 248-255).

It is commonly accepted that the gaming sector is made up of four main groups of actors (Cadin and Guerin, 2006; Dymek and Rehn, 2003; Kerr, 2006): game developers/producers, game publishers, game distributors and console manufacturers. From the developer's perspective and on the basis of the mentioned actors, one can distinguish four relationships found in the gaming industry (Klimas, 2015):

1) relationships between game developers - cooperation and competition; 
2) relationships between game developers and game publishers - cooperation related to various phases of designing and producing the game;

3) relationships between game developer and the distribution company-cooperation related to the sales and distribution of a game;

4) relationships between a game developer and a console manufacturer-cooperation related to game design and production. Complying with and leveraging technological standards offered by consoles.

The characteristics of a game as a product result in relationships formed not only within the gaming industry but also with other industries. Klimas indicated seven such industries (2015):

1. Film industry - incorporating film plots into computer games or the other way round, e.g. the use of the world depicted in "Star Wars" films in "Star Wars Jedi: Fallen Order," a game made by Respawn Entertainment.

2. TV - incorporating plot of TV series or TV shows into a computer game or the other way round, the example being "Sonic the Hedgehog," an animated series based on the game of the same title issued by the Japanese game publisher SEGA.

3. Publishing industry - bringing the literary universe to computer games, e.g. the Polish studio CD Project RED's use of the universe created in the "Witchcraft" saga by Andrzej Sapkowski in the computer game of the same title.

4. Toy industry - creating toys based on game characters.

5. Sports industry - enabling players to do some home exercise with motion controllers for sports games (e.g. "Kinect Sport") and using real sports licenses within games, e.g. professional football league licenses in FIFA 2020.

6. Music industry - enabling players to pursue their passion for music in games where they sing or play an instrument, e.g. "Singstar" or "Guitar Hero," and using music tracks in games.

7. Fashion industry - enabling players to pursue their passion for fashion - e.g. with "Cover Fashion" from CrowdStar.

The contemporary computer gaming market has a great impact on society and other industries and clearly manifests itself in many realms of life. In addition to the mentioned industries, connections with games and the computer gaming market can nowadays found at every turn. There are coffee cups with game themes, mobile phone manufacturers offering phones-cum-gaming consoles and numerous coffee shops and bars catering for the gaming community.

\section{Growth of the computer gaming industry}

Nowadays, the wide availability of computers, phones and the Internet drives the rapid growth of the computer gaming market, bringing increasingly high revenues both in Poland and globally. 
The report on the global gaming industry delivered by the analytics and research company Newzoo (2019) shows that the value of the global gaming market in 2019 was USD 152.1 billion, 10\% more than the year before. Importantly, the value of that market in 2022 is expected to exceed USD 195 billion, which would mean a 27\% increase within four years.

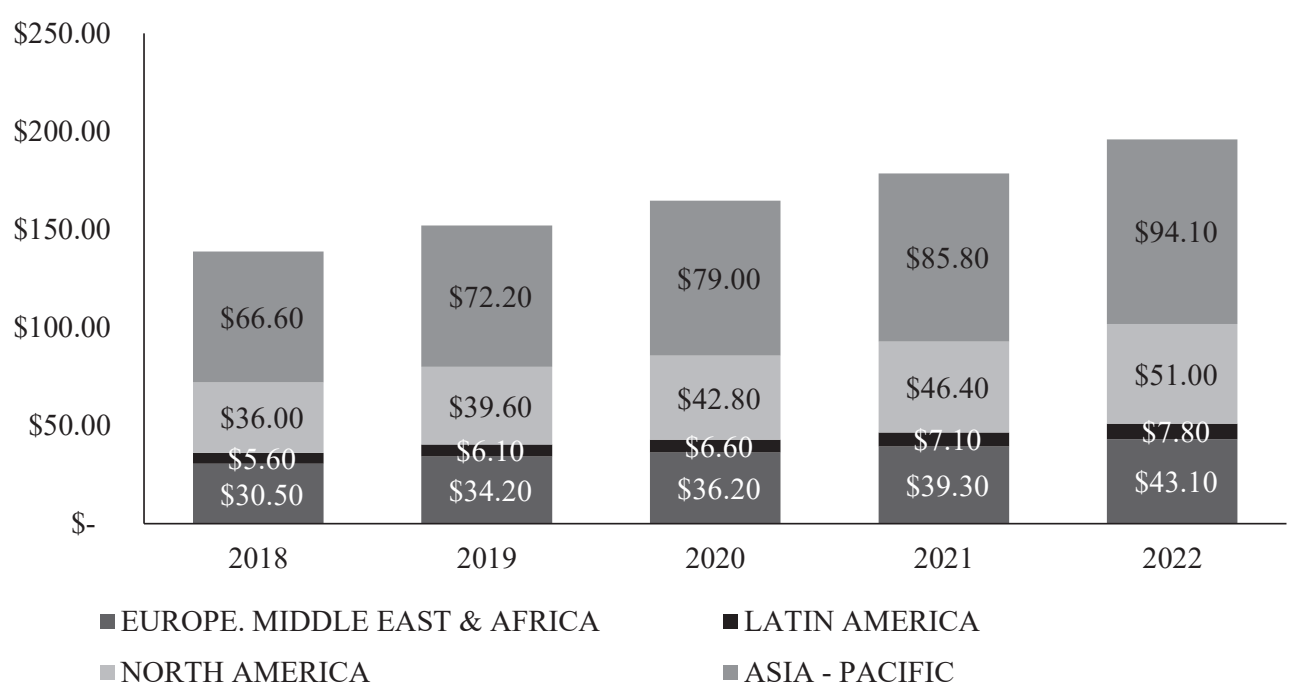

Fig. 4. Regional breakdown of global game revenues, up to 2022

Source: Global games market report (Newzoo, 2019).

Revenues in this sector differ for specific regions and countries, with Asia being the global leader of the gaming market (USD 72.2 billion, around $7.6 \%$ of annual growth). The biggest revenues in this region occur in China: ca. USD 36.5 billion, and the world's second most profitable market is North America, with USD 39.6 billion of revenues in 2019 (ca. 11.7\% increase vs. the previous year). Europe is the third most profitable region of the world, with estimated gaming revenues of USD 29.9 billion.

The revenues of the computer games industry can also be divided for various gaming platforms. The report provided by Newzoo distinguished five of them: console games, tablet games, smartphone games, PC games and web-browser games. The largest gaming market in terms of platforms is made up by smartphone games, and its value in 2019 was USD 54.9 billion, an annual increase of $11.6 \%$. The second position is the console gaming market, which generates USD 47.9 billion (an annual increase of $13.4 \%$ ), and $\mathrm{PC}$ games make up the third most profitable platform, worth USD 32.2 billion, an increase of about $6.6 \%$ against the previous year. Interestingly, it was estimated that the revenues of the PC gaming market are going to drop in the coming years in favour of console and smartphone games. 
The computer games market in Poland has seen a dynamic growth over the past few years. A report developed by Zenit Management (2019) shows that the gaming development companies constitute the biggest and fastest-growing group of companies on the Warsaw Stock Exchange in the past few years. In mid 2019, the Polish stock exchange comprised the world's third largest number of game development companies. The value of shares of gaming companies increased in the first half-year by more than $35 \%$. The largest growth in recent years was observed by CD Project RED, with a listed value of PLN 26.7 billion as of the end of 2019 (ahead of Bank Pekao).

\section{Gaming industry research}

The growth of the computer gaming industry has sparked significant interest not just among economic analysts but also researchers such as sociologists and economists since the rising popularity of games has made the industry a strong global sector rapidly reinventing global culture (Castranova, 2005). For several years now, we have observed a number of research projects committed to the evolution of the gaming industry, its specific characteristics and impact on human lives, and in the late 1990s the game studies emerged as a distinct branch of the humanities.

One of the prominent researchers investigating game theory and the gaming industry is J. Juul, who in his book entitled "Half Real: Video Games Between Real Rules and Fictional Worlds" (2005), pointed to, among other things, the boundary between the world created by computer games and the real world, to which, drawing upon Huzinga's work, he refers to as the 'magic circle'. This circle basically consists of all elements of the game that do not relate to the real world and have no impact on it. Just as a football or a basketball game is played out on a field, a computer game should be played just on a certain platform (Juul, 2005). His work has resulted in a number of books, the classics of world game theory, including: "A Casual Revolution: Reinventing Video Games and Their Players", where the author demonstrates how the view of computer games has evolved in recent years and how the demographics has changed.

The Chinese computer gaming market is the fastest-growing gaming market in the world. In the past few decades, China has seen the rise of a unique gaming scene. For the majority of Chinese users, a computer, a console or another gaming device is the equivalent of a classic TV set. The dynamic growth of Asia's computer gaming industry makes this region very attractive to analysts and researchers, e.g. N. Kshetri, who studies the Chinese gaming industry. The author touches upon, among other things, the evolution of the Chinese computer gaming market, the differences between the Asian region and the rest of the world; and the impact and use of computer games in the country's everyday and political lives. In "The Evolution of the Chinese Online Gaming Industry," Kshetri stresses the use of online games as a platform useful for 
spreading nationalistic and patriotic slogans among Chinese young people (Kshetri, 2010; Liu, 2005). From the analytical and research perspective, it is also important to note how the gaming industry reflects the evolution of Chinese culture and business. A large number of international companies, e.g. Pepsi, Audi and McDonald's, use games as an alternative advertising platform for its users. According to a report by Niko Partners, by 2023 there will be more than 350 million regular PC-only players in China, excluding mobile platforms (China PC Games, 2019). The author also addresses the emergence of a separate market for virtual objects, which players can obtain by playing games and then sell for real money. One example of such a transaction is the sale of a cosmetic item in a game called "Counter-Strike: Global Offensive" for USD 100,000. It is worth noting that most of the items sold on the virtual market have collector's value, only. In his research, Kshetri seeks to answer the following questions. What is the state of computer game market in China? How do the government and businesses respond to changes in the gaming market? Is the impact range of the computer gaming industry global?

Some research projects on topics related to the computer gaming industry have been carried out in Poland, too. One of the particularly notable researchers in this field is P. Klimas, who has investigated, among others, the evolution of business models in the gaming industry as well as the relationships among market actors. In the article entitled "Key Resources in Game Developers' Business Models" (Klimas, 2018), she presents the results of research aimed at identifying the key resources used by game developers. The research was of a qualitative nature and was conducted in the form of surveys addressed to Polish game developers, showing that, for video game creators, it is pointless to separately assess people and their knowledge, and human resources are the most essential assets. This insight is in line with the concept of creative industries, which are mainly based on knowledge and human resources. Thirdly, it was demonstrated that the analysis of certain forms of assets helps us identify hidden employees' knowledge, something especially important to Polish game developers. Fourthly, relational assets were shown to be the missing element of the four-dimensional model developed by Osterwadler and Pigneur (2010). It was eventually demonstrated that the identification of the assets perceived by game developers is essential to their business as well as potentially interested new entities.

\section{Conclusion}

The creative industry is one of the most promising economic sectors in the world. It spans a number of various industries marked by high creativity and innovativeness. Production involves small companies yet distribution is dominated by large businesses (Klasik, 2010). The support for the growth of the creative industry is regarded as an important trend towards the greater competitiveness of cities and regions. In the past few years, the computer gaming industry, considered as one of 
cultural industries, has seen very dynamic growth, and the available analyses show that this industry is generating increasingly higher annual revenues, and this trend will likely be sustained.

The computer games industry is a very attractive subject for scientific inquiry. Computer games are a comparatively new form of entertainment and thus for many years have been disregarded in analyses and studies. With the growth of the gaming industry, this market in question and the games themselves have become a very rewarding research topic. Across the world, including Poland, researchers are increasingly committed to investigating the industry which is dominated by China.

Today's computer gaming market is essentially different from that of the 1990s. Due to the specificity of the value chain, year-by-year analysis of the growth of the video game industry seems to be a very interesting research theme. It is also worth mentioning the hybrid product sales model, with the products being increasingly offered both in the traditional form, as a 'digital key' or on a subscription basis. The changes occurring in the video game industry are also driven by technological development. The new generations of video game consoles and graphic engines push developers to make continuous changes. In the future, new technologies such as VR (virtual reality) may revolutionize the global entertainment industry.

In analysing the video game industry, it is worth noting the increasingly popular streaming services and e-sport. E-sports competitions attract not only an increasingly big audience but also investors. E-sport, an offshoot of the video game industry, seems to be a very attractive topic of inquiry. Due to its growing popularity, developers and city authorities increasingly recognize the opportunities offered by this kind of entertainment. Large cities host e-sport events, which impact both the video game industry and local communities. In many cases, these events act as magnets and attract scores of participants. Regarding potential future studies, it is worth recognizing the numerous investments projects associated with the industry in question. An example of such an investment is the Katowice technological HUB, likely to become Poland's gaming centre. Looking into the future, it is worth pointing to the nexus between the development of the video game industry and the growth of cities and regions, which can play the role of a driving force for these areas.

\section{References}

Balland, P. A., Boschma, R., and Franken, K. (2012). Proximity and innovation networks: An evolutionary approach. In P. Cooke (Ed.) Re-farming regional development: Evolution, innovation and transition. New York: Routledge.

Bankov, B. (2019). The impact of social media on video games communities and the gaming industry. Varna: University of Economics in Varna.

Cadin, L., and Guerin, F. (2006). What can we learn from the video games industry? European Management Journal, 24(4), 248-255. 
Castranova, E. (2005). Synthetic worlds: The business and culture of online games. University of Chicago Press.

Cellmer, A. (2012). Miara kreatywności na bazie wybranych modeli i teorii przemystów kreatywnych. Katowice: Wydawnictwo Uniwersytetu Ekonomicznego w Katowicach.

DCMS. (1998). Creative industries mapping document. Retrieved from http://www.gov.uk

Drobniak, A. (2012). Kultura i przemysly kreatywne - doświadczenia, tendencje rozwojowe, nowe obszary badawcze w miastach. Katowice: Wydawnictwo Uniwersytetu Ekonomicznego w Katowicach.

Dymek, M., and Rehn, A. (2003). Polygonmakarna: Spelbanschens högteknologiska upplevelseekonomi. Stockholm: Royal Institute of Technology, Department of Industrial Economist and Management.

Fesel, B., and Sondermann, M. (2007). Culture and Creative Industries in Germany. Bonn: German Commission for UNESCO.

Florida, R. (2002). The rise of the creative class: And how it's transforming work, leisure and community. New York: Basic Books.

Florida, R. (2005). Cities and the Creative Class. New York: Routledge.

Huizinga, J. (1992). Homo Ludens. Zabawa jako źródto kultury. Warszawa: Wydawnictwo Czytelnik.

Juul, J. (2005). Half-real: Video games between real rules and fictional worlds. MIT Press.

Kerr, A. (2006). Digital games as cultural industry. London: Sage.

Klasik, A. (Ed.). (2010). Rola sektora kultury i przemystów kreatywnych w rozwoju miast i aglomeracji. Katowice: Wydawnictwo Uniwersytetu Ekonomicznego w Katowicach.

Klasik, A. (2011). Kreatywne przemysty - kreatywne aglomeracje. Warszawa: Biuletyn Komitetu Przestrzennego Zagospodarowania Kraju Polskiej Akademii Nauk.

Klasik, A. (Ed.). (2014). Sektor kreatywny jako katalizator przemian strukturalnych w regionie. Katowice: Wydawnictwo Uniwersytetu Ekonomicznego w Katowicach.

Klasik, A. (Ed.). (2018). Rozwój kreatywny i inteligentny centrów i przestrzeni miejskich. Katowice: Wydawnictwo Uniwersytetu Ekonomicznego w Katowicach.

Klimas, P. (2015). Sieci relacji producentów gier komputerowych i video. Zeszyty Naukowe Wyższej Szkoły Bankowej w Poznaniu, 7(63).

Klimas, P. (2018). Key resources in game developers' business models. Journal of Management and Financial Science, (31).

Klimas, P. (2019). Relacje współtworzenia innowacji w ekosystemach. Kontekst ekosystemu gamingowego. Warszawa: C.H. Beck.

Kshetri, N. (2010). The evolution of the Chinese online gaming industry. Journal of Technology Management in China, 4(2).

Liu, J. (2005). Pirates pillage China's online game industry. USA Today.

Newzoo. (2019). Global games market report. Retrieved from http://www.newzoo.com

Niko. (2019). China PC Online Games Market Report. Retrived from https:nikopartners.com

Osterwalder A., and Pigneur Y. (2010) Business Model Generation. New Jersey: John Wiley \& Sons, Inc.

Perron, B., and Wolf, M. J. P. (Eds.). (2005). The video game theory reader. London: Routledge.

Pięta-Kanurska, M. (2013). Wpływ sektora kreatywnego na ksztaltowanie się polskich metropolii. Wrocław: Wydawnictwo Uniwersytetu Ekonomicznego we Wrocławiu.

Potts, J., and Cunningham, S. (2008). Four models of the creative industries. International Journal of Cultural Policy, 120(1).

Scholz, T. M. (2012). Talent management in the video game industry: The role of cultural diversity and cultural intelligence. Thunderbird International Business Review, 54(6).

Throsby, D. (2008). The concentric circles model of the cultural industries. Cultural Trends, 17(3), 147-164 . 
Tschang, F. T. (2005). Videogames as interactive experimental products and their manner of development. International Journal of Innovation Management, 9(1).

Tschang, T. (2007). Balancing the tensions between rationalization and creativity in the video games industry. Organization Science, 18(6).

Zackariasson, P., and Wilson, T. L. (Eds.). (2009). Creativity in the video game industry. New York: Routledge.

Zackariasson, P., and Wilson, T. L. (Eds.). (2012). The video game industry: Formation, present state, and future. New York: Routledge.

Zenit Management. (2019). Poland Gaming Sector. Retrieved from http://www.zenit.com.pl 